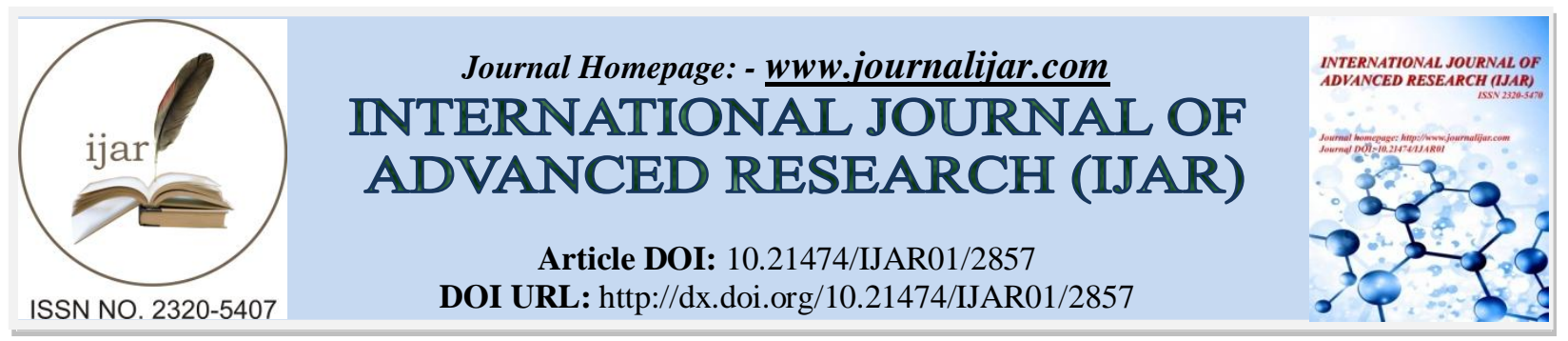

RESEARCH ARTICLE

\title{
IDENTIFYING EPIGENETIC ENDPOINTS OF PESTICIDE EXPOSURE CAN CURTAIL RISK TO DEVELOP CANCER: A REVIEW.
}

\author{
Rituparna Das ${ }^{1 *}$, Kulbhushan Thakur ${ }^{2 *}$, Anju Shrivastava ${ }^{3}$, Akshita Puri ${ }^{3}$ and Mousumi Mutsuddi ${ }^{1}$. \\ 1. Department of Molecular and Human Genetics, Institute of Science, Banaras Hindu University, Varanasi, India \\ 2. Department of Zoology, Institute of Science, Banaras Hindu University, Varanasi, India \\ 3. Department of Zoology, Delhi University, New Delhi, India
}

\section{Manuscript Info}

................................

Manuscript History

Received: 21 November 2016

Final Accepted: 21 December 2016

Published: January 2017

Key words:-

Pesticides, Epigenetics, Cancer risk.

\section{Abstract}

Potential for carcinogenicity of pesticides is identified on the basis of its potential for causing genotoxicity. But, there are some pesticides that do not cause mutation at very early stage of exposure but result in silencing certain genes which make the cells addicted to oncogenic products to become neoplastic. This review throws light on the epigenetic changes brought about by pesticides, which effect the expression of genes without change in their DNA sequence. If certain epigenetics based tests are included in the panel of screening pesticides before they are introduced into the market, then not only will it help in deciding norms for regulating exposure to these chemicals but will also solidify our knowledge for that pesticide.

Copy Right, IJAR, 2016,. All rights reserved.

\section{Introduction:-}

Pesticides are group of chemicals designed to eliminate pests, including insects, molds and unwanted plants, in order to protect crops. Based on their targets the pesticides are categorized as fungicides, insecticides, herbicides etc.

Pesticides are neurotoxins, nephrotoxins, genotoxins, hemotoxins and endocrine disrupters for the target organisms. Thus regulation of their exposure and usage is important for protecting the non-target organisms. One of the most undesirable effects of the pesticides on the non-target organisms is development of cancer. The pesticides are tested for genotoxicity and carcinogenicity before authorization for marketing (Bull, Fletcher, Boobis and Battershill, 2006). But, there are several epidemiological studies that indicate association of chronic exposure to certain pesticides with increased risk of cancer (See Table I). This suggests that possibly long term exposure to pesticides eventually brings about neoplastic changes to the cells via mechanisms other than genoxicity (Tsai and Baylin, 2011; Baccarelli and Bollati, 2009; Mostafalou \& Abdollahi, 2013).

Pesticides can result in carcinogenesis via multiple mechanisms like oxidative stress, several receptor mediated pathways and aberrant epigenetic changes (Alavanja, Ross and Bonner, 2013). Epigenetic modifications of tumor suppressor genes and oncogenes are considered important molecular drivers for tumorigenesis and are crucial for cancer diagnostics. Study of epigenetic signatures for exposure to environmental chemicals is a developing field (Hou, Zhang, Wang, \& Baccarelli, 2012).

Corresponding Author:- Rituparna Das.

Address:- Department of Molecular and Human Genetics, Institute of Science, Banaras Hindu

University, Varanasi, India. 
Table I:- Some epidemiological studies to study role of pesticide exposure on different cancer types prevalent in the population

\begin{tabular}{|c|c|c|c|c|c|c|c|c|}
\hline $\begin{array}{l}\text { S. } \\
\mathbf{N} \\
\mathbf{O} .\end{array}$ & $\begin{array}{c}\text { TYPE } \\
\text { OF } \\
\text { CANCE } \\
\text { R }\end{array}$ & $\begin{array}{c}\text { TYPE OF } \\
\text { PESTICID } \\
\text { E } \\
\text { EXPOSUR } \\
\text { E }\end{array}$ & $\begin{array}{c}\text { POPULATI } \\
\text { ON } \\
\text { STUDIED }\end{array}$ & $\begin{array}{c}\text { AGE OF } \\
\text { SUBJEC } \\
\text { TS }\end{array}$ & $\begin{array}{c}\text { TYPE OF } \\
\text { DATA } \\
\text { COLLECTI } \\
\text { ON }\end{array}$ & $\begin{array}{c}\text { TIME } \\
\text { SPAN } \\
\text { OF } \\
\text { STUD } \\
\text { Y }\end{array}$ & $\begin{array}{l}\text { REMARKS / } \\
\text { CONCLUSI } \\
\text { ONS }\end{array}$ & References \\
\hline 1 & $\begin{array}{l}\text { Brain } \\
\text { tumor }\end{array}$ & $\begin{array}{l}\text { Occupation } \\
\text { al pesticide } \\
\text { exposure }\end{array}$ & $\begin{array}{l}\text { Rio-de- } \\
\text { Janerio }\end{array}$ & $\begin{array}{l}\text { Men } \\
\text { (age } \\
>18)\end{array}$ & $\begin{array}{c}\text { Death } \\
\text { certificates } \\
\text { from health } \\
\text { centers }\end{array}$ & $\begin{array}{l}1998- \\
2005\end{array}$ & $\begin{array}{l}\text { Agricultural } \\
\text { workers } \\
\text { showed } \\
\text { higher } \\
\text { mortality risk } \\
\text { due to brain } \\
\text { cancer than } \\
\text { non-farm } \\
\text { workers }\end{array}$ & $\begin{array}{c}\text { (Miranda- } \\
\text { Filho, } \\
\text { Monteiro, \& } \\
\text { Meyer, 2012) }\end{array}$ \\
\hline 2 & $\begin{array}{l}\text { Prostate } \\
\text { cancer }\end{array}$ & $\begin{array}{c}\text { OP: } \\
\text { Malathione } \\
\text {. Fonofos, } \\
\text { Turbufos ; } \\
\text { OC: } \\
\text { Aldrein }\end{array}$ & $\begin{array}{l}\text { Iowa and } \\
\text { North } \\
\text { Carolina }\end{array}$ & $\begin{array}{c}\text { Men } \\
\text { (age not } \\
\text { defined) }\end{array}$ & $\begin{array}{c}\text { Interviews } \\
\text { based on } \\
\text { questionnair } \\
\mathrm{e}\end{array}$ & $\begin{array}{l}1993- \\
2007\end{array}$ & $\begin{array}{c}\text { Association } \\
\text { of increased } \\
\text { risk of total } \\
\text { prostrate } \\
\text { cancer with } \\
\text { increased use } \\
\text { of Fonofos } \\
\text { and Aldrein } \\
\text { in those with } \\
\text { family } \\
\text { history. }\end{array}$ & $\begin{array}{c}\text { (Koutros et al., } \\
\text { 2013) }\end{array}$ \\
\hline 3 & $\begin{array}{l}\text { Multiple } \\
\text { sites }\end{array}$ & $\begin{array}{l}\text { Occupation } \\
\text { al pesticide } \\
\text { exposure }\end{array}$ & $\begin{array}{l}\text { Andalusia } \\
\text { (Spain) }\end{array}$ & $\begin{array}{c}\text { Men and } \\
\text { women } \\
\text { (average } \\
\text { age 37) }\end{array}$ & $\begin{array}{l}\text { Hospital } \\
\text { records }\end{array}$ & $\begin{array}{l}1998- \\
2005\end{array}$ & $\begin{array}{l}\text { Prevalence } \\
\text { higher in } \\
\text { areas with } \\
\text { higher } \\
\text { exposure. } \\
\text { Males show } \\
\text { higher cases } \\
\text { of lung, } \\
\text { prostate, and } \\
\text { testicular } \\
\text { cancers. } \\
\text { Females } \\
\text { show higher } \\
\text { cases of } \\
\text { ovary and } \\
\text { breast } \\
\text { cancer. }\end{array}$ & $\begin{array}{c}\text { (Parrón, } \\
\text { Requena, } \\
\text { Hernández, \& } \\
\text { Alarcón, 2013) }\end{array}$ \\
\hline 4 & $\begin{array}{c}\text { Childhoo } \\
\text { d } \\
\text { leukemia } \\
\text { ALL, } \\
\text { AML }\end{array}$ & $\begin{array}{c}\text { Occupation } \\
\text { al pesticide } \\
\text { exposure }\end{array}$ & $\begin{array}{c}\text { Europe (13 } \\
\text { nationwide } \\
\text { studies) }\end{array}$ & $\begin{array}{c}\text { Children } \\
\text { (mostly } \\
\text { of age } \\
15 \text { ) and } \\
\text { parents }\end{array}$ & $\begin{array}{l}\text { Data from } \\
\text { study done } \\
\text { by } C L I C\end{array}$ & $\begin{array}{l}\text { Variab } \\
\text { le }\end{array}$ & $\begin{array}{c}\text { Increased } \\
\text { risk of AML } \\
\text { with } \\
\text { maternal } \\
\text { exposure to } \\
\text { pesticides } \\
\text { during } \\
\text { pregnancy. } \\
\text { Slight } \\
\text { increase in } \\
\text { the ALL } \\
\text { with paternal } \\
\text { exposure to }\end{array}$ & $\begin{array}{l}\text { (Bailey et al., } \\
\text { 2014) }\end{array}$ \\
\hline
\end{tabular}




\begin{tabular}{|c|c|c|c|c|c|c|c|c|}
\hline & & & & & & & pesticides & \\
\hline 5 & $\begin{array}{c}\text { Non- } \\
\text { Hodgkin } \\
\text { s } \\
\text { Lympho } \\
\text { ma }\end{array}$ & $\begin{array}{c}\text { Many } \\
\text { lifestyle } \\
\text { associated } \\
\text { factors, } \\
\text { diet, } \\
\text { occupation } \\
\text { al exposure } \\
\text { to } \\
\text { pesticides }\end{array}$ & $\begin{array}{l}\text { Mumbai } \\
\text { (India) }\end{array}$ & $\begin{array}{c}\text { Men } \\
\text { (average } \\
\text { age 46) }\end{array}$ & $\begin{array}{l}\text { Data from } \\
\text { TATA } \\
\text { memorial } \\
\text { hospital } \\
\text { followed by } \\
\text { interview }\end{array}$ & $\begin{array}{l}1997- \\
1999\end{array}$ & $\begin{array}{l}3 \mathrm{X} \text { increase } \\
\text { in lymphoma } \\
\text { on exposure } \\
\text { to pesticides. }\end{array}$ & $\begin{array}{l}\text { (Balasubramani } \\
\text { am, Saoba, } \\
\text { Sarade, \& } \\
\text { Pinjare, 2013) }\end{array}$ \\
\hline 6 & $\begin{array}{c}\text { Hodgkin } \\
\text { s } \\
\text { Lympho } \\
\text { ma }\end{array}$ & $\begin{array}{l}\text { Multiple } \\
\text { pesticides }\end{array}$ & $\begin{array}{l}6 \text { provinces } \\
\text { of Canada }\end{array}$ & $\begin{array}{l}\text { Men } \\
\text { (age } \\
>19)\end{array}$ & $\begin{array}{l}\text { Data from } \\
\text { CCSPH } \\
\text { followed by } \\
\text { interview }\end{array}$ & $\begin{array}{l}1991- \\
1994\end{array}$ & $\begin{array}{c}\text { Association } \\
\text { of Hodgkins } \\
\text { Lymphoma } \\
\text { with } \\
\text { fungicides } \\
\text { and } \\
\text { insecticides } \\
\text { specially } \\
\text { acetylcholine } \\
\text { esterase } \\
\text { inhibitors }\end{array}$ & $\begin{array}{l}\text { (Navaranjan et } \\
\text { al., 2013) }\end{array}$ \\
\hline 7 & $\begin{array}{c}\text { Childhoo } \\
\mathrm{d} \\
\text { leukemia } \\
\text { ALL, } \\
\text { AML }\end{array}$ & $\begin{array}{l}\text { Occupation } \\
\text { al pesticide } \\
\text { exposure }\end{array}$ & India & $\begin{array}{l}\text { Children } \\
\text { (age }<18) \\
\text { and } \\
\text { parents }\end{array}$ & $\begin{array}{c}\text { Patients } \\
\text { from } \\
\text { (PBDSHUH } \\
\text { S) followed } \\
\text { by } \\
\text { questionnair } \\
\text { e }\end{array}$ & $\begin{array}{l}2008- \\
2012\end{array}$ & $\begin{array}{l}\text { Increase in } \\
\text { the risk } \\
\text { leukemia in } \\
\text { children } \\
\text { whose } \\
\text { mothers are } \\
\text { working in } \\
\text { agricultural } \\
\text { field during } \\
\text { pregnancy }\end{array}$ & $\begin{array}{c}\text { (Kumar, } \\
\text { Vashist, \& } \\
\text { Rathee, 2014) }\end{array}$ \\
\hline 8 & $\begin{array}{c}\text { Stomach } \\
\text { Pancreati } \\
\text { c } \\
\text { Leukemi } \\
\text { a }\end{array}$ & $\begin{array}{l}\text { Organochlo } \\
\text { ric } \\
\text { pesticides } \\
\text { DDT }\end{array}$ & $\begin{array}{c}\text { Sardinia } \\
\text { (Italy) }\end{array}$ & $\begin{array}{l}\text { Men and } \\
\text { Women } \\
\text { (age not } \\
\text { defined) }\end{array}$ & ........ & $\begin{array}{l}1984- \\
1986\end{array}$ & $\begin{array}{l}\text { Mortality } \\
\text { from } \\
\text { stomach } \\
\text { cancer } \\
\text { increased up } \\
\text { to } 2 \mathrm{X} \text { in high } \\
\text { exposure. } \\
\text { But no } \\
\text { exposure- } \\
\text { response } \\
\text { trend was } \\
\text { observed. }\end{array}$ & $\begin{array}{c}\text { (Cocco et al., } \\
1997)\end{array}$ \\
\hline 9 & $\begin{array}{c}\text { Colorect } \\
\text { al } \\
\text { Cancer }\end{array}$ & $\begin{array}{c}50 \\
\text { Occupation } \\
\text { al pesticide } \\
\text { exposure }\end{array}$ & $\begin{array}{l}\text { Iowa and } \\
\text { North } \\
\text { Carolina }\end{array}$ & $\begin{array}{c}\text { Not } \\
\text { defined }\end{array}$ & $\begin{array}{c}\text { Exposure } \\
\text { details by } \\
\text { questionnair } \\
\mathrm{e}\end{array}$ & $\begin{array}{l}1993- \\
1997\end{array}$ & $\begin{array}{l}\text { Chlorpyrifos } \\
\text { and Aldicarb } \\
\text { exposure } \\
\text { associated } \\
\text { with } \\
\text { colorectal } \\
\text { cancer }\end{array}$ & $\begin{array}{c}\text { (Lee et al., } \\
\text { 2010) }\end{array}$ \\
\hline 10 & $\begin{array}{l}\text { Bladder } \\
\text { Cancer }\end{array}$ & $\begin{array}{c}\text { Occupation } \\
\text { al pesticide } \\
\text { exposure }\end{array}$ & France & $\begin{array}{c}\text { men (age } \\
35-74)\end{array}$ & $\begin{array}{c}\text { Data from } \\
\text { Pesticide } \\
\text { Exposure } \\
\text { Index for } 89 \\
\text { units in } \\
\text { France } \\
\end{array}$ & $\begin{array}{l}1984- \\
1986\end{array}$ & $\begin{array}{l}\text { A significant } \\
\text { link with PEI } \\
\text { in vineyards } \\
\text { was found }\end{array}$ & $\begin{array}{c}\text { (Viel \& } \\
\text { Challier, 1995) }\end{array}$ \\
\hline
\end{tabular}




\begin{tabular}{|c|c|c|c|c|c|c|c|c|}
\hline 12 & $\begin{array}{c}\text { Stomach, } \\
\text { Kidney } \\
\text { etc }\end{array}$ & $\begin{array}{c}\text { Occupation } \\
\text { al pesticide } \\
\text { exposure }\end{array}$ & $\begin{array}{c}\text { Central } \\
\text { Italy }\end{array}$ & $\begin{array}{c}\text { Men } \\
\text { (age 35- } \\
80)\end{array}$ & $\begin{array}{l}\text { Data from } \\
\text { Municipal } \\
\text { registration }\end{array}$ & 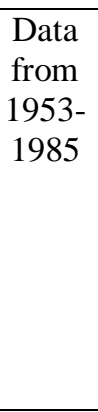 & $\begin{array}{c}\text { Increased } \\
\text { risk of } \\
\text { stomach and } \\
\text { kidney } \\
\text { cancer } \\
\text { among men } \\
\text { with }>10 \\
\text { years of } \\
\text { pesticide } \\
\text { exposure }\end{array}$ & $\begin{array}{c}\text { (Forastiere et } \\
\text { al., 1993) }\end{array}$ \\
\hline 13 & $\begin{array}{l}\text { Thyroid } \\
\text { Cancer }\end{array}$ & $\begin{array}{l}\text { Fungicide } \\
\text { Mancozeb }\end{array}$ & Norway & $\begin{array}{c}\text { Men and } \\
\text { Women } \\
\text { (age 30- } \\
75 \text { ) and } \\
\text { children } \\
\text { (age }<10 \\
\text { ) }\end{array}$ & $\begin{array}{c}\text { data from } \\
\text { different } \\
\text { census } \\
\text { reports }\end{array}$ & $\begin{array}{l}1974- \\
1989\end{array}$ & $\begin{array}{c}\text { Mild } \\
\text { association } \\
\text { between } \\
\text { Mancozeb } \\
\text { and Neural } \\
\text { tube defects } \\
\text { and no } \\
\text { association } \\
\text { was found } \\
\text { between } \\
\text { mancozeb } \\
\text { exposure and } \\
\text { thyroid } \\
\text { cancer }\end{array}$ & $\begin{array}{c}\text { (Nordby, } \\
\text { Andersen, } \\
\text { Irgens, \& } \\
\text { Kristensen, } \\
\text { 2005) }\end{array}$ \\
\hline
\end{tabular}

Even before the genetic mutations show up, there are a set of modifications in the genome without changing the sequence of DNA, events that can change the fate of a cell. These are called epigenetic modifications. These modifications in a normal cell maintain a stable state of suitable gene expression and are responsible for cell differentiation and genomic imprinting. Their aberrations lead to aberrant gene expression and ultimately render the cell addicted to oncogenic product. There are piling reports that have proved association of epigenetic aberrations with development of chronic disorders, especially if the aberration occurs in the early stage of life (Sharma, Kelly and Jones, 2010). (See Box I)

Genetic changes are rare and take time to show up, epigenetic changes get perturbed easily in response to change in the micro-environment of its cell. There are certain attributes that makes epigenetics an attractive field medical advances (See Box II).

Epigenetics can help understand the molecular mechanisms altered by non-genotoxic Carcinogens. These can prove to be the key to solve issues associated with rising cases of cancers associated with occupational exposure of pesticides and also give some insight into mechanisms involved in environment influenced disease pathogenesis. Pesticide exposure during early stages of life results in epigenetic modifications in the cell. This may form the basis for developing diseases later in life (Shuk-Mei Ho, et. al., 2012). Malansky in 1981 suspected epigenetic mode for tumorigenicity in hepatocytes by organochloric pesticides which had no observable genotoxicity (Maslansky \& Williams, 1981). Over the decades immense reporting has been done to unveil different mechanisms involved in influence of ecotoxicants on our epigenome. 


\section{BOX I: EPIGENETICS - BASIC INTRODUCTION}

The Branch of Biology that studies interaction between genotypes and phenotypes of a cell that decides the final outcome of a locus, without altering a DNA sequence of a cell (Goldberg, Allis and Bernstein, 2007). It reflects the transcription status of the cell based on its past cellular events. Epigenetic changes are heritable (Bonasio, Tu and Reinberg, 2010). Epigenetic pattern are decided by DNA methylation at CpG islands in genic or non genic regions of the genome, post translational histone modifications like methylation, acetylation, ubiquitylation, phosphorylation and micro RNA.

DNA Methylation: Major proportion of 5-methyl cytosines are located at $\mathrm{CpG}$ islands in the genome. These changes are brought about by DNA methyltransferases (DNMTs).

Covalent modifications of Histone Tails: Histones are basic octamer proteins that help in packaging of DNA. Histones constitute of $2 \mathrm{H} 3,2 \mathrm{H} 4$ and dimers of H2A and H2B. The covalent modifications of histone tails are dynamically and strictly regulated by different enzymes. Histone acetyltransferases (HATs) and histone methyltransferases (HMTs) add acetyl and methyl groups, respectively, whereas histone deacetylase (HDACs) and histone demethylases (HDMs) remove acetyl and methyl groups, respectively. Histone acetylation at lysine is strictly associated with transcription activation of genes. But histone methylation has different impact on the transcription status of the gene based on the position of methyl group. Histone modifications have been shown to be important in altering chromatin structure and therefore DNA accessibility. Histones modifications along with DNA methylation can regulate gene expression, chromatin remodeling, cell survival and cell death.

MiRNA: These are single-stranded RNAs of about 21-23 nucleotides in length that are transcribed from DNA but not translated into proteins (non-coding RNAs). Their functional role is gene expression regulation mediated by a control of messenger RNA (mRNA) stability or translation. ncRNA can be small or long. Small ncRNA interact with RNA, DNA or RNA-DNA triplet or recruit modifiers. Long ncRNA form complex structures that have domains to interact with modifier or RNA Polymerase II and target base pair sequence (Bonasio et al., 2010).

Simple epigenetic assays can be introduced in the panel of tests that are performed for approval of pesticides and as biomarkers for post marketing assessment for toxicity of pesticides. This can make understanding the efficacy of pesticides clearer and can complement the assays for carcinogenicity. .

This review discusses about different epigenetic alterations that are brought about by some of the known pesticides. Studies on aberrant epigenetic alterations caused by pesticide exposure would not only help us to identify the chemicals that are potential carcinogens, but also open new arenas to assess health of non-target population exposed to pesticides at chronic or acute levels, thereby define better safety biomarkers (Thomson, et. al., 2013) because Epigenetic aberrations pave path for cancer development or development of chronic diseases later in life (Feinberg and Tycko, 2004).

\section{Epigenetic link between pesticides and chronic diseases:-}

The pesticides are approved based on antimicrobial testing, movement of pesticides in soil, water, plant and environment and residues in the food-feed, animal commodities and extensive carcinogenicity testing before regulatory approval. But pesticide exposure has repeatedly been associated with various cancers. The usual tests that are used to validate carcinogenicity are based on genotoxicity that include mutagenicity. Several ecotoxicants that were traditionally known to be non-mutagenic are now considered as epimutagens owing to their detrimental effects on the epigenome of the people coming in contact with these (Hou, Zhang, Wang and Baccarelli, 2012). Some of these chemicals are summarized in Table II.

Mammalian germ cells and pre-implantation embryos undergo critical process of imprinting, regulated epigenetically, that lays grounds for differential reprogramming (Sasaki and Matsui, 2008). Presence of xenobiotics or their derivatives during these critical periods can induce persistent and heritable epigenetic changes. Anway et al. showed gestational exposure of endocrine disruptor Vinclozolin, a common dicarboximide fungicide, induced 


\section{BOX II: EPIGENETICS - CLINICAL APPLICATIONS}

Epigenome off lately has caught attention of the medical field also. Apart from its implications in environmental issues, it has now started being considered as important as the genome of the individual for diagnosis of cancer. There are number of genes whose expression is involved in normal cell cycle, apoptosis, cell adhesion, angiogenesis or some way or the other associated with suppression of tumor. But as cancer develops the expression of these genes is suppressed by genetic or epigenetic mechanisms. Genetic alterations like mutations show up later in the cancer development if the cause is not congenital. Silencing by hypermethylation of genes like RASSF1A, p16, APC, MLH1, SEPT9, CDH1 have been implicated in many cancers and can be detected early in tumor development (Li, Jin, \& Wang, 2014)(Y.-J. Zhang et al., 2007)(Brock et al., 2008).

Genetic mutations are not always conclusive about malignancy of the tumor, the signature of cancer. Certain disorders that exploit the same pathways for its development as cancer may also show similar genetic mutations, like the case of Chronic Obstructive Pulmonary Disorder (COPD) and lung cancer. Rather epigenetic alterations are more conclusive about cancer development eg. CDKN21 hypermethylation (Brothers et al., 2013).

Frequency of hypermethylation of SFRP and Basonuclein 1 has been found to be associated with survival of renal cell carcinoma patients. These modifications are better markers than tumor dimension (Ricketts, Hill, \& Linehan, 2014).

Inclusion of such panels of non-invasive, highly sensitive and specific genome-wide epigenetic biomarkers for different types of cancers can drastically improvise the efficiency of cancer diagnosis.

Versatility and recognition of epigenetics can be appreciated by the fact that FDA has approved some anti cancer drugs like Azacitidine, Decitabine that exploit epigenetic mechanisms to suppress cancer development.

Table II:- Epigenetic pathways exploited by different pollutants

\begin{tabular}{|c|c|c|c|c|}
\hline $\begin{array}{l}\text { POLLUTA } \\
\text { NTS }\end{array}$ & $\begin{array}{l}\text { CARCIN } \\
\text { OGEN }\end{array}$ & MUTAGEN & $\begin{array}{c}\text { EPIGENETIC MECHANISM } \\
\text { OF ACTION }\end{array}$ & REFERENCES \\
\hline \multicolumn{5}{|c|}{ Metals } \\
\hline Cadmium & Yes & Mild & $\begin{array}{l}\text { Inhibit DNMT by interfering in } \\
\text { enzyme-DNA interaction }\end{array}$ & $\begin{array}{c}\text { (Takiguchi, Achanzar, Qu, Li, \& } \\
\text { Waalkes, 2003) }\end{array}$ \\
\hline Arsenic & Yes & $\begin{array}{c}\text { Yes in high } \\
\text { concentration }\end{array}$ & $\begin{array}{c}\text { Inhibit DNMT by limiting } \\
\text { availability of SAM for DNMT }\end{array}$ & $\begin{array}{c}\text { (Srivastava, D’Souza, Sen, \& } \\
\text { States, 2008) }\end{array}$ \\
\hline Nickel & Yes & $\begin{array}{c}\text { Inhibit } \\
\text { excision repair }\end{array}$ & $\begin{array}{l}\text { In vitro studies reflect reduced } \\
\text { histone acetylation }\end{array}$ & $\begin{array}{l}\text { (Ke, Davidson, Chen, Kluz, \& } \\
\text { Costa, 2006) }\end{array}$ \\
\hline Chromium & Yes & $\begin{array}{c}\text { Only by } \\
\text { hexavalent } \\
\text { salts }\end{array}$ & $\begin{array}{l}\text { In vitro studies reflect altered } \\
\text { histone modifications }\end{array}$ & $\begin{array}{c}\text { (Schnekenburger, Talaska, \& } \\
\text { Puga, 2007) }\end{array}$ \\
\hline $\begin{array}{l}\text { Methyl } \\
\text { Mercury }\end{array}$ & Yes & Moderate & $\begin{array}{c}\text { Epigenetic suppression of } \\
\text { BDNF }\end{array}$ & $\begin{array}{l}\text { (Onishchenko, Karpova, Sabri, } \\
\text { Castrén, \& Ceccatelli, 2008) }\end{array}$ \\
\hline $\begin{array}{l}\text { TCE, DCA, } \\
\text { TCA }\end{array}$ & $\begin{array}{c}\text { Rodent } \\
\text { carcinogen }\end{array}$ & $\begin{array}{l}\text { Only in very } \\
\text { high doses }\end{array}$ & $\begin{array}{l}\text { Decreased methylation of } 2 \\
\text { proto-oncogenes }\end{array}$ & $\begin{array}{c}\text { (Moore and Harrington Brock, } \\
2000)\end{array}$ \\
\hline $\begin{array}{c}\text { Air } \\
\text { Pollution }\end{array}$ & $\begin{array}{l}\text { PAH is } \\
\text { carcinogen } \\
\text { ic }\end{array}$ & $\begin{array}{l}\text { PAH is } \\
\text { mutagenic }\end{array}$ & $\begin{array}{l}\text { Reduced global DNA } \\
\text { methylation levels }\end{array}$ & $\begin{array}{c}\text { (Ehrlich, 2002) (Alexandra Ya. } \\
\text { Khesina, 2004) }\end{array}$ \\
\hline Benzene & Yes & $\begin{array}{l}\text { Benzene oxide } \\
\text { is mutagenic }\end{array}$ & $\begin{array}{l}\text { Changes in the DNA } \\
\text { methylation pattern }\end{array}$ & $\begin{array}{l}\text { (Bollati et al., 2007) (R P } \\
\text { Chilcott, 2007) }\end{array}$ \\
\hline RDX & Yes & Yes & Modify miRNA expression & $\begin{array}{l}\text { (Zhang \& Pan, 2009) (Bhuhan } \\
\text { B. et al 2003) }\end{array}$ \\
\hline \multicolumn{5}{|c|}{ Endocrine-disrupting Chemicals } \\
\hline Diethylstilbe & Yes & No & Inhibit methylation by & (H.R. Glatt, 1979) \\
\hline
\end{tabular}




\begin{tabular}{|c|c|c|c|c|}
\hline strol (DES) & & & $\begin{array}{c}\text { inhibiting COMT gene } \\
\text { transcription }\end{array}$ & \\
\hline $\begin{array}{c}\text { Bisphenol A } \\
\text { (BPA) }\end{array}$ & Yes & No & $\begin{array}{c}\text { Modify DNA methylation } \\
\text { pattern }\end{array}$ & (Dolinoy, Huang, \& Jirtle, 2007) \\
\hline
\end{tabular}

From data obtained from Epigenetics and environmental chemicals (Baccarelli \& Bollati, 2011) and other sources

multiple abnormalities in the mice offsprings for at least 3 generations (Nilsson, Anway, Stanfield and Skinner, 2008). Presence of ecotoxicants in the microenvironment during early stages of life can greatly perturb epigenome thereby the whole cellular function especially thereby making the organism susceptible to develop disorders during later stages of life (Jirtle and Skinner, 2007).

Arsenic, a semi-metal frequently used as pesticide, easily found to contaminate water sources and has been linked to cancer of the bladder, lungs, skin, kidney, nasal passages, liver, and prostate. Arsenic is used in wood preservatives, paints, dyes, metals, drugs, soaps and semi-conductors. Though its genotoxic effects are known it's also known to affect the epigenome. Hypomethylation of LINE repeat has also being associated with low level Arsenic exposure in Mexican children (Alegría-Torres et al., 2016). Arsenic is also associated with hypermethylation mediated silencing of p16 and p53 genes in a dose dependent manner in the people of West Bengal, one of the most Arsenic contaminated regions in the world, and is strongly correlated to arsenic induced skin lesions in people (Chanda et al., 2006). High Pesticide Exposure Events has been correlated with elevated DNA methylation of GSTP1 promoter among pesticide applicators older than 59 years of age (Rusiecki et al., 2016). GSTP1 promoter hypermethylation is associated with prostate cancer (Gonzalgo et al., 2003). Inorganic arsenic is biologically detoxified by methylation catalyzed by S-adenosine methionine methyltransferase (reviewed by Ajees and Rosen, 2015). Excess arsenic in the body lowers activity of DNMTs by cofactor restriction, required to maintain the proper methylation status of the cell. Hyper and hypomethylation due to arsenic exposure are reported at both, gene specific and genome specific levels and the mechanism of its action is not yet clearly elucidated (reviewed by Reichard and Puga, 2010).

Arsenic has been shown to alter miRNAs expression, involved in a carbon metabolism, in human lymphoblastoid cells (Marsit, Eddy and Kelsey, 2006).

For its adverse effects on human health all arsenic derivative pesticides except Monosodium methanearsonate (MSMA) have been banned under EPA 2009. The residual Arsenic content present in soil and water still pose severe health risks.

Persistent Organic Pollutants (POPs) are chemical substances that persist in the environment, bioaccumulate through the food web and pose a risk of causing adverse effects to human health and the environment. POPs are global concern because POPs can be transported across international boundaries far from their sources. Their effects on wildlife species, even in areas where these are not produce have raised alarm on their implications in humans. Human exposure in the arctic regions is among the highest in world. Their main route to enter is via food and its endocrine disrupting role linked them to reproductive impairment in humans. They are also reported to cause immune system disruption. 12 of these POPs have been targeted by UNEP for global elimination based on the extensive reports of their persistence, though association of these chemicals with chronic diseases in humans is incomplete.

Most POPs are either insecticide related products or are produced in industries. Rusiecki et al reported association of high serum concentration of a panel of POPs including DDT, Chlordane Mirex, PCB, hexachlrobenzene and Toxaphene with decrease in the global methylation status in the Alu repeat regions of Greenlandic Inuit population (Rusiecki et al., 2008). The association between global hypomethylation with genomic instability might explain the increasing rate of cancer in this area. Similar results were obtained by a different group of investigators for a population (South Korea) with much lower biological concentration of POPs as compared to Greenlandic Inuit (Kim et al., 2010).

Another study done by Shutoh et. al. reported DNA hypomethylation at 6 specific gene promoter sites and at global level on vivo exposure to DDT in a dose dependent manner (Shutoh et al., 2009). DDT can induce production of reactive oxygen species (Pérez-Maldonadoa et al., 2005). Low levels of $5 \mathrm{mC}$ induced by Hypoxia is responsible for solid tumor formation in presence of ROS (Shahrzad, Bertrand, Minhas, \& Coomber, 2007). Another recent report 
suggests tumor hypoxia mediated reduction in the activity of Ten Eleven Translocase (TET) enzyme results in hypermethylation of promoter regions as TET mediates oxidative demethylation of 5mC (Thienpont et al., 2016).

DDT is now banned for agricultural purposes but is used for vector control in some countries. Due to lack of mutagenicity it is considered only a probable carcinogen to humans by EPA 1987. Similarly Chlordane is now banned but its non-mutagenicity do not compliment its link to prostate and breast cancers development and affects the nervous system. An occupational study reported association between chlordane exposure and non-Hodgkins's lymphoma. EPA has classified chlordane as a Group B2, probable human carcinogen. Mirex is banned as pesticide in US but is used in other products. It is a non mutagen but is a carcinogenic risk to humans. PCBs have widespread utilities apart from pesticides and are known to be associated with liver cancer in spite of being a non-mutagen. According to EPA, PCBs are probable human carcinogens (B1). Toxaphene (EPA Group B2) has limited mutagenicity but is highly toxic to liver, kidney, spleen, adrenal and thyroid glands, CNS, and the immune system. Chronic oral exposure to hexachlorobenzene (EPA Group B2), now banned in US is associated with a liver disease with associated skin lesions. Epidemiologic studies of people exposed to hexachlorobenzene have not shown an increased cancer incidence. However, animal studies have reported cancer of the liver.

Dieldrin, another dreaded POP insecticide, is associated with non-mutagenic carcinogenesis in mouse but lack of human evidence makes it most probable human carcinogen (Stevenson et al., 1999) and is linked to Parkinson's disease, breast cancer and immune, reproductive and nervous system damage. Its persistence, like other POP has made it one of the red listed chemicals for EPA. Aberrant histone modifications were observed under the influence of this POP by Song et. al. they observed short term and long term in-vitro effect on mammalian cell. Long term, small dose treatment was more environmentally relevant and was observed to result in hyperacetylation of $\mathrm{H} 3$ and H4 after 6-24 hrs of treatment on the dopaminergic neuronal cells. In-vivo treatment of the same resulted in hyperacetylation of $\mathrm{H} 4$ in striatum of mice brain, the part associated with Parkinson's. They linked this finding to accumulation of a HAT. The epigenetic impact on the dopaminergic neuronal cells may give some clue to understand relation between Parkinson's and dieldrin exposure (Song, Kanthasamy, Anantharam, Sun, \& Kanthasamy, 2010).

Apart from these 7 of the 12 United Nations Environment Programme (UNEP) targeted POPs for global elimination (May 2001), there are other organic pollutants also that are not so much a threat in terms of persistence. Fonofos is a commonly used pesticide in most of the countries and is non carcinogenic. Parathion is a commonly used insecticide for many crops. No epidemiological information is available on reproductive, developmental, or carcinogenic effects of parathion in human population. Limited data on animals are available; increased adrenal cortical tumors were observed in rats orally exposed to parathion. EPA has classified parathion as a Group C, possible human carcinogen. Both, Parathione (Velázquez, Xamena and Creus, 2009) and Fonofos are nonmutagenic. But Zhang et al reported alteration in the methylation status of 712 genes in response to treatment of these organophosphate pesticides (X. Zhang et al., 2013). This may account for sparse reports that are available on the chronic impacts of these pesticides (Bonner et al., 2010).

Triazophos and Dichlorovos are organophosphate pesticides that are used for agricultural purposes in most of the countries in the world. No information is available on the reproductive, developmental, or carcinogenic effects of dichlorovos on humans. A study by the National Toxicology Program (NTP) reported an increased incidence of tumors of the pancreas, mammary glands, and forestomach in animals. EPA has classified dichlorovos as a Group B2, probable human carcinogen though mutagenicity of dichlorovos is disputed (Ashwood-Smith, Trevino and Ring, 1972; Carere, Ortali, Cardamone and Morpurgo, 1978). There is no active registration for Triazophos under EPA but Triazophos is non mutagenic (Velázquez et al., 2009). It is non carcinogenic in animals but carcinogenicity is controversial in human. Ross et al analyzed tumorigenic triazophos and dichlorovos, and non tumorigenic myclobutanil, a fungicide, and observed that though all the three pesticides result in the negative fold change of 19 different miRNAs, the alteration observed for the two tumorigenic pesticides was times more than the non tumorigenic pesticide. These alterations can be potential markers for effect of tumorigenic conazoles in mouse at 90 day of exposure, when there was no tumor or neoplasticity observed. Secondly, the genes whose mRNAs are targeted by these miRNAs are probably important for tumorigenesis. They also concluded that there probably a threshold of downregulation of miRNAs is required to be attained for causing tumorigenesis, which is not attained by the non-tumorigenic myclobutanil (Ross et al., 2010). The epigenetic aberrations reported for these OP pesticides, might give clue to the chronic neurotoxicity associated impacts of organophosphorus pesticides (Rastogi, Tripathi and Ravishanker, 2010). 
There are many pesticides that are not Persistent Organic Pollutants, but are associated with occurrence of chronic disorders. Paraquat, a herbicide, is associated with respiratory disorder on high exposure (Dalvie et al., 1999). It shows mild direct mutagenicity and is categorized as a Group E pesticide (showing no evidence of carcinogenicity). Song et al reported impact of Paraquat on epigenome of mammalian cells. They observed that Hyperacetylation is responsible for paraquat induced neurotoxicity using N27 Dopaminergic Neuronal cells with decrease in the total HDAC activity after Paraquat exposure (Song, Kanthasamy, Jin, Anantharam and Kanthasamy, 2011). Such hyperacetylation might lead to aberrant activation of genes.

Propiconazole is a fungicide and anti microbial pesticide. No mutagenicity is associated with this pesticide and EPA has classified propiconazole as Group C for carcinogenicity (possible human carcinogen). Fipronil, a insecticide, is associated with no evident chronic impact and U.S. EPA classified fipronil as Group C - possible human carcinogen. In a vivo study on zebrafish showed alteration in miRNA levels after treatments with propiconazole and fipronil. Alteration of different miRNAs expression was observed in response to individual and combinatorial treatments. It suggests that efficacies of exposure to these pesticides in isolation or in combination, may be varied or summative (Xingxing Wang, Zhou, Ding, Zhu and Guo, 2010).

\section{BOX III: EPIGENETICCS vs. GENETICS}

It is now established that cancer progression in due to interplay between epigenetic and genetic mechanisms. Now studies have shifted from studying silencing classical Tumor Suppression Genes to studying candidate TSGs based on the hyper or hypomethylation of promoter regions of cells with characteristic neoplastic phenotype. Following are certain aspects that make packing of DNA as important as the sequence of the genome.

$\checkmark$ Genetic changes involve premutagenic damage like strand breakage, mutagenic damage and chromosomal aberrations. Epigenetic changes involve changes in the DNA methylation pattern histone acetylation pattern and altered miRNA expression.

$\checkmark$ Epigenetic alterations can be detected at the early stages of cancer. The genetic alterations characterize the tumor formation or metastatic stage of cancer. Thus effect of any alteration in the microenvironment can be understood more quickly with the help of epigenetic alterations it causes.

$\checkmark$ Familial genetic mutation may not show up in a population till it is homozygous. It gets diluted by mating with non-mutants. Whereas epigenetic silencing can occur in multiple individuals and appear to be more persistent. It raises the probability of developing a disorder later in life.

$\checkmark$ Genetic mutations are more stable and irreversible than the epigenetic alterations. Thus the latter opens good prospects for treatment of chronic disorders before occurance of severe mutations restrict the treatment.

$\checkmark$ For a given tumor growth there are seldom multiple mutations because only one hit is sufficient to disrupt the complete pathway. Whereas for gene silencing there are many such disruptions that can be associated with a single tumor suppressing pathway. These aberrations recruit other modifiers also. Their notoriety makes them detectable over a wide range.

These all evidences of impact of pesticides on our epigenome suggest there are many other mechanisms that may give rise to environment induced cancer. There are several mechanisms at play that lead to altered cell physiology, epigenomic aberrations being one of them. So if we restrict the use of pesticide with proper regulations, we can curtail the threat (Alavanja et al., 2013). The carcinogenicity status assigned to these pesticides by EPA, IARC and NTP and usage status in India have been summarized in table III. 
Table III:- Brief overview of some common pesticides.

\begin{tabular}{|c|c|c|c|c|c|}
\hline PESTICIDES & TYPE & $\begin{array}{c}\text { IARC / } \\
\text { EPA / NTP }\end{array}$ & $\begin{array}{l}\text { USAGE IN } \\
\text { INDIA }\end{array}$ & $\begin{array}{l}\text { MECHANIS } \\
\text { M STUDIED } \\
\text { IN THE } \\
\text { REVIEW } \\
\end{array}$ & REFERENCES \\
\hline $\begin{array}{c}\text { Dichloro } \\
\text { Diphenyl } \\
\text { Trichloroethan } \\
\text { e (DDT) }\end{array}$ & $\begin{array}{l}\text { Organochlor } \\
\text { ic } \\
\text { Insecticide }\end{array}$ & $\begin{array}{l}\text { IARC 2B } \\
\text { NTP - } \\
\text { RAHC }\end{array}$ & $\begin{array}{l}\text { largest } \\
\text { producer and } \\
\text { sole exporter } \\
\text { with } \\
\text { restricted use }\end{array}$ & $\begin{array}{c}\text { DNA } \\
\text { Methylation }\end{array}$ & $\begin{array}{l}\text { (cibrc.nic.in/ibr2012. } \\
\text { doc) }\end{array}$ \\
\hline Mirex & $\begin{array}{l}\text { Organochlor } \\
\text { ic } \\
\text { Insecticide }\end{array}$ & $\begin{array}{c}\text { IARC - 2B } \\
\text { NTP - } \\
\text { RAHC }\end{array}$ & $\begin{array}{l}\text { banned for } \\
\text { manufacture, } \\
\text { import and } \\
\text { use } \\
\end{array}$ & $\begin{array}{c}\text { DNA } \\
\text { Methylation }\end{array}$ & $\begin{array}{c}\text { (Bhuvaneshwari, Rajendran, \& } \\
\text { Nadu, 2012) }\end{array}$ \\
\hline L-chlordane & $\begin{array}{l}\text { Organochlor } \\
\text { ic } \\
\text { Insecticide }\end{array}$ & IARC - 2B & $\begin{array}{l}\text { banned for } \\
\text { manufacture, } \\
\text { import and } \\
\text { use }\end{array}$ & $\begin{array}{c}\text { DNA } \\
\text { Methylation }\end{array}$ & $\begin{array}{c}\text { (cibrc.nic.in/ibr2012. } \\
\text { doc) } \\
\text { (IARC, 1991) }\end{array}$ \\
\hline $\begin{array}{l}\text { Polychlorinate } \\
\text { d biphenyles } \\
\text { (PCBs) }\end{array}$ & $\begin{array}{l}\text { Organochlor } \\
\text { ic } \\
\text { Insecticide }\end{array}$ & $\begin{array}{c}\text { IARC - 2A } \\
\text { NTP - } \\
\text { RAHC }\end{array}$ & $\begin{array}{l}\text { Present in } \\
\text { dietary } \\
\text { intake }\end{array}$ & $\begin{array}{c}\text { DNA } \\
\text { Methylation }\end{array}$ & (IARC, 1991) \\
\hline $\begin{array}{l}\text { Monosodium } \\
\text { methanearsona } \\
\text { te (MSMA) - } \\
\text { OAP }\end{array}$ & Herbicide & $\begin{array}{c}\text { Only } \\
\text { Arsenical } \\
\text { pesticides } \\
\text { permitted by } \\
\text { US EPA } \\
2009\end{array}$ & \multirow{4}{*}{$\begin{array}{c}\text { High } \\
\text { concentratio } \\
\text { ns of } \\
\text { arsenic have } \\
\text { been } \\
\text { measured in } \\
\text { drinking- } \\
\text { water } \\
\text { include large } \\
\text { areas } \\
\text { in West } \\
\text { Bengal. } \\
\text { Used mainly } \\
\text { for cotton } \\
\text { crops. }\end{array}$} & $\begin{array}{c}\text { DNA } \\
\text { Methylation }\end{array}$ & \multirow[t]{4}{*}{$\begin{array}{c}\text { IARC Monograph } \\
\text { (post } 2004 \text { on Arsenic And } \\
\text { Arsenic Compounds) }\end{array}$} \\
\hline $\begin{array}{l}\text { Disodium } \\
\text { methanearsona } \\
\text { te (DSMA) }\end{array}$ & Herbicide & $\begin{array}{l}\text { IARC - } 3 \\
\text { Prohibited } \\
\text { under } \\
\text { US EPA } \\
2009 \\
\end{array}$ & & $\begin{array}{c}\text { DNA } \\
\text { Methylation }\end{array}$ & \\
\hline $\begin{array}{l}\text { calcium acid } \\
\text { methanearsona } \\
\text { te (CAMA) }\end{array}$ & Herbicide & $\begin{array}{l}\text { Prohibited } \\
\text { under } \\
\text { US EPA } \\
2009 \\
\end{array}$ & & $\begin{array}{c}\text { DNA } \\
\text { Methylation }\end{array}$ & \\
\hline cacodylic acid & Herbicide & $\begin{array}{l}\text { Prohibited } \\
\text { under } \\
\text { US EPA } \\
2009 \\
\end{array}$ & & $\begin{array}{c}\text { DNA } \\
\text { Methylation }\end{array}$ & \\
\hline Fonofos & $\begin{array}{c}\text { OP } \\
\text { insecticide }\end{array}$ & $\begin{array}{c}\text { Not } \\
\text { Classified } \\
\text { by IARC } \\
\text { Category E } \\
\text { in US EPA }\end{array}$ & $\begin{array}{l}\text { Common } \\
\text { agricultural } \\
\text { usage }\end{array}$ & $\begin{array}{c}\text { DNA } \\
\text { Methylation }\end{array}$ & EPA Red Facts (Fonofos 1999) \\
\hline Terbufos & $\begin{array}{c}\text { OP } \\
\text { nematicide } \\
\text { and } \\
\text { insecticide }\end{array}$ & $\begin{array}{c}\text { Not } \\
\text { classified by } \\
\text { IARC } \\
15 \text { percent } \\
\text { or more } \\
\text { terbufos are } \\
\text { classified as } \\
\text { RUPs }\end{array}$ & $\begin{array}{l}\text { Used to } \\
\text { control corn } \\
\text { rootworms. }\end{array}$ & $\begin{array}{c}\text { DNA } \\
\text { Methylation }\end{array}$ & US EPA \\
\hline Parathion & $\begin{array}{l}\text { OP } \\
\text { insecticide } \\
\text { and }\end{array}$ & $\begin{array}{c}\text { IARC - } 3 \\
\text { Category C } \\
\text { by US EPA }\end{array}$ & $\begin{array}{l}\text { Methyl } \\
\text { parathion } \\
\text { under }\end{array}$ & $\begin{array}{c}\text { DNA } \\
\text { Methylation }\end{array}$ & $\begin{array}{c}\text { (cibrc.nic.in/ibr2012.doc)(IARC, } \\
1991)\end{array}$ \\
\hline
\end{tabular}




\begin{tabular}{|c|c|c|c|c|c|}
\hline & acaricide. & & $\begin{array}{c}\text { restricted } \\
\text { use. } \\
\text { Ethyl } \\
\text { parathion } \\
\text { banned for } \\
\text { manufacture, } \\
\text { import and } \\
\text { use } \\
\end{array}$ & & \\
\hline Dieldrin & $\begin{array}{c}\mathrm{OC} \\
\text { insecticide }\end{array}$ & $\begin{array}{l}\text { IARC - 3 } \\
\text { No current } \\
\text { use in US }\end{array}$ & $\begin{array}{c}\text { banned for } \\
\text { manufacture, } \\
\text { import and } \\
\text { use }\end{array}$ & $\begin{array}{c}\text { Histone } \\
\text { modification }\end{array}$ & $\begin{array}{c}\text { (cibrc.nic.in/ibr2012.doc)(IARC, } \\
\text { 1991) }\end{array}$ \\
\hline Paraquat & Herbicide & $\begin{array}{c}\text { Not } \\
\text { classified by } \\
\text { IARC } \\
\text { Category E } \\
\text { by US EPA } \\
1997 \\
\text { Though } \\
\text { restricted or } \\
\text { banned in } \\
\text { many } \\
\text { countries }\end{array}$ & $\begin{array}{c}\text { Paraquat } \\
\text { Dimethyl } \\
\text { Sulphate } \\
\text { banned for } \\
\text { manufacture, } \\
\text { import and } \\
\text { use. } \\
\text { Paraquat } \\
\text { dichloride is } \\
\text { avidly used } \\
\text { and } \\
\text { registered }\end{array}$ & $\begin{array}{c}\text { Histone } \\
\text { modification }\end{array}$ & $\begin{array}{l}\text { (cibrc.nic.in/ibr2012.doc) } \\
\text { (PANAP Feb 2011) }\end{array}$ \\
\hline Triadimefon & Fungicide & $\begin{array}{c}\text { Not } \\
\text { Classified } \\
\text { by IARC } \\
\text { Category C } \\
\text { by US EPA }\end{array}$ & $\begin{array}{l}\text { Registered } \\
\text { under } \\
\text { CIBRC and } \\
\text { used in } \\
\text { many states }\end{array}$ & $\begin{array}{l}\text { miRNA based } \\
\text { regulation }\end{array}$ & $\begin{array}{l}\text { (www.cdms.net/ldat/) } \\
\text { State of pesticide regulations in } \\
\text { India (CSE) }\end{array}$ \\
\hline Propiconazole & Fungicide & $\begin{array}{c}\text { Not } \\
\text { Classified } \\
\text { by IARC } \\
\text { Propiconazo } \\
\text { le is a } \\
\text { General Use } \\
\text { Pesticide. }\end{array}$ & $\begin{array}{l}\text { Registered } \\
\text { under } \\
\text { CIBRC and } \\
\text { used in } \\
\text { many states } \\
\text { for many } \\
\text { crops }\end{array}$ & $\begin{array}{l}\text { miRNA based } \\
\text { regulation }\end{array}$ & $\begin{array}{c}\text { State of pesticide regulations in } \\
\text { India (CSE) } \\
\text { (http://www.toxipedia.org/) }\end{array}$ \\
\hline Myclobutanil & Fungicides & $\begin{array}{c}\text { Not } \\
\text { Classified } \\
\text { by IARC } \\
\text { Myclobutani } \\
1 \text { is a } \\
\text { General Use } \\
\text { Pesticide. }\end{array}$ & $\begin{array}{l}\text { Registered } \\
\text { under } \\
\text { CIBRC and } \\
\text { used in } \\
\text { many states } \\
\text { for Apple }\end{array}$ & $\begin{array}{l}\text { miRNA based } \\
\text { regulation }\end{array}$ & $\begin{array}{c}\text { State of pesticide regulations in } \\
\text { India (CSE) } \\
\text { (http://www.toxipedia.org/ ) }\end{array}$ \\
\hline Fipronil & Insecticides & $\begin{array}{c}\text { Not } \\
\text { Classified } \\
\text { by IARC } \\
\text { Category C } \\
\text { by US EPA }\end{array}$ & $\begin{array}{l}\text { Registered } \\
\text { under } \\
\text { CIBRC and } \\
\text { used in } \\
\text { many states } \\
\text { for } \\
\text { sugarcane } \\
\text { and cotton } \\
\text { (no MRL) } \\
\end{array}$ & $\begin{array}{l}\text { miRNA based } \\
\text { regulation }\end{array}$ & $\begin{array}{l}\text { State of pesticide regulations in } \\
\text { India (CSE) (NPIC) }\end{array}$ \\
\hline
\end{tabular}




\begin{tabular}{|c|c|c|c|c|c|}
\hline Triazophos & $\begin{array}{c}\text { OP } \\
\text { insecticide }\end{array}$ & $\begin{array}{c}\text { Not } \\
\text { registered } \\
\text { with the } \\
\text { EPA for use } \\
\text { as pesticide } \\
\text { in the US } \\
\text { Banned in } \\
\text { the EU for } \\
\text { use }\end{array}$ & $\begin{array}{c}\text { Registered } \\
\text { under } \\
\text { CIBRC and } \\
\text { used in } \\
\text { many states } \\
\text { for paddy } \\
\text { and cotton } \\
\text { Dichlorovos }\end{array}$ & $\begin{array}{c}\text { miRNA based } \\
\text { regulation }\end{array}$ & $\begin{array}{c}\text { State of pesticide regulations in } \\
\text { India } \\
\text { (CSE) } \\
\text { (http://hazmap.nlm.nih.g } \\
\text { ov/) }\end{array}$ \\
\hline insecticide & $\begin{array}{c}\text { Not } \\
\text { Classified } \\
\text { by IARC } \\
\text { Category B2 } \\
\text { by US EPA } \\
\text { (probable } \\
\text { human } \\
\text { carcinogen) }\end{array}$ & $\begin{array}{c}\text { Broad } \\
\text { application }\end{array}$ & $\begin{array}{c}\text { miRNA based } \\
\text { regulation }\end{array}$ & (http://www.epa.gov/) \\
& & & \\
\hline
\end{tabular}

\section{Conclusion:-}

To minimize the risk of cancer due to pesticide usage, strategically refined regulatory parameters need to be laid down. These parameters should be based on the research aimed to correctly identify the chemicals that are potential carcinogens. This would help in successful reduction of harmful exposure to workers and general public thereby curbing the risk of developing cancer.

Genotoxicity testing includes identification of genetic alterations such as mutation in genes involved in tumorigenesis or the chromosomal aberrations in number or structure. But such tests are not complete for identification of non-genotoxic carcinogens (Thomson, Moggs, Wolf and Meehan, 2013). For now it is well known that not only our genome, but our epigenome also regulates the cellular functions. Early appearance and higher plasticity of epigenetic changes as compared to genetic changes (Box III) make them attractive subject to determine the disease endpoints for different pesticides.

To assess this scenario of increasing cases of cancer in pesticide exposed population we need to look beyond just the genotoxic effects of pesticides. Heritability of epigenetic changes makes them crucial biomarkers for studying the long term and short term effect of the pesticide exposure on the gene expression. Thus integrating epigenetic and transcriptomic studies can give insight into effects at early stages of exposure and predict the long term effect of the chronic exposure of the pesticides more accurately (Thomson et al., 2013).

Eventually pesticide exposure specific signature databases can be generated based on epigenomic and transcriptomic research data. The pinnacle authorities for pesticide approval like EPA, CIRBC etc can bring about suitable amendments in their guidelines for approval and registration. But prior to this sufficient scientific research is required to understand the role of epigenetic endpoints in the toxicity. Though epigenetic safety is a developing field of research but it holds the promise to deeper understanding of xenobiotic exposures and their role in disease progression in the long term and understanding the environment associated pathology of different diseases. 


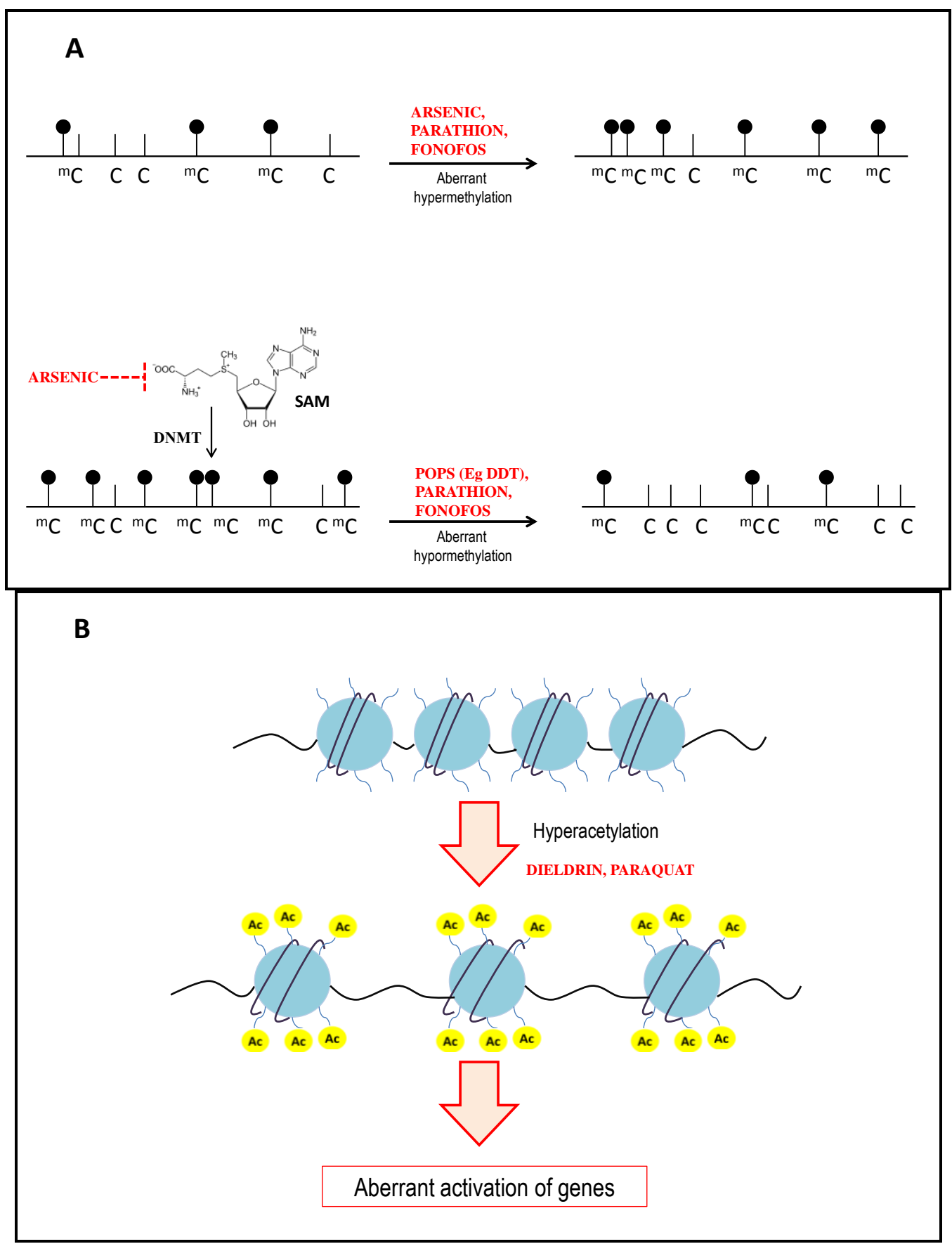

Fig I:- Role of pesticides in aberrant activation of genes via DNA methylation and histone acetylation.

Pesticides are reported to alter the DNA methylation (A) and histone acetylation (B) status of the cells. Both these mechanis ms contribute to abnormal activation of certain genes and genomic instability, making the cells vulnerable to become neoplastic.

1. Ajees, A. A., \& Rosen, B. P. (2015). As(III) S-adenosylmethionine methyltransferases and other arsenic binding proteins. Geomicrobiol J., 32, 570-576.

2. Alavanja, M. C. R., Ross, M. K., \& Bonner, M. R. (2013). Increased Cancer Burden Among Pesticide Applicators and Others Due to Pesticide Exposure. CA: A Cancer Journal for Clinicians, 63, 120-142.

3. Alegria-Torres, J. A., Carrizales-Y, L., Rosso-Camacho, F., Motta, V., Tarantini, L., \& Bollati, V. (2016). DNA Methylation Changes in Mexican Children Exposed to Arsenic From Two Historic Mining Areas in San Luis Potosi. Environmental andMolecularMutagenesis.

4. Ashwood-Smith, M. J., Trevino, J., \& Ring, R. (1972). Mutagenicity of Dichlorvos. Nature, 240, 418-420.

5. Baccarelli, A., \& Bollati, V. (2009). Epigenetics and environmental chemicals. Curr Opin Pediatr., 21(2), 243- 
251.

6. Bonasio, R., Tu, S., \& Reinberg, D. (2010). Molecular Signals of Epigenetic States. Science, 330, 612-616.

7. Bonner, M. R., Williams, B. A., Rusiecki, J. A., Blair, A., Beane, L. E., Hoppin, J. A., Dosemeci, M., Lubin, J., Sandler, D. P., Alavanja, M. C. R. (2010). Occupational Exposure to Terbufos and the Incidence of Cancer in the Agricultural Health Study. Cancer Causes Control., 21(6), 871-877.

8. Brock, M. V, Hooker, C. M., Ota-Machida, E., Han, Y., Guo, M., Ames, S., Glöckner, S., Piantadosi, S., Gabrielson, E., Pridham, G., Pelosky, K., Belinsky, S.A., Yang, S.C., Baylin, S.B., Herman, J. G. (2008). DNA methylation markers and early recurrence in stage I lung cancer. The New England Journal of Medicine, 358,1118-1128.

9. Brothers, J. F., Hijazi, K., Mascaux, C., El-zein, R. A., Spitz, M. R., \& Spira, A. (2013). Bridging the clinical gaps: genetic , epigenetic and transcriptomic biomarkers for the early detection of lung cancer in the postNational Lung Screening Trial era. BMC Medicine, 11(1), 1.

10. Bull, S., Fletcher, K., Boobis, A. R., \& Battershill, J. M. (2006). Evidence for genotoxicity of pesticides in pesticide applicators : a review. Mutagenesis, 21(2), 93-103.

11. Carere, A., Ortali, V. A., Cardamone, G., \& Morpurgo, G. (1978). Mutagenicity Of Dichlorvos And Other Structurally Related Pesticides In Salmonella And Streptomyces*. Chem.-Biol. Interactions, 22, 297-308.

12. Chanda, S., Dasgupta, U. B., Guhamazumder, D., Gupta, M., Chaudhuri, U., Lahiri, S., Das, S., Ghosh, N., Chatterjee, D. (2006). DNA Hypermethylation of Promoter of Gene p53 and p16 in Arsenic-Exposed People with and without Malignancy. Toxicological Science, 89(2), 431-437.

13. Dalvie, M. A., White, N., Raine, R., Myers, J. E., London, L., Thompson, M., \& Christiani, D. C. (1999). Long term respiratory health effects of the herbicide, paraquat, among workers in the Western Cape. Occup Environ Med, 56, 391-396.

14. Feinberg, A. P., \& Tycko, B. (2004). The history of cancer epigenetics. Nature Reviews Cancer, 4, 143-153.

15. Goldberg, A. D., Allis, C. D., \& Bernstein, E. (2007). Essay Epigenetics : A Landscape Takes Shape, Cell, 128, 635-638.

16. Gonzalgo, M. L., Pavlovich, C. P., Lee, S. M., Nelson, W. G., James, T., \& Brady, B. (2003). Prostate Cancer Detection by GSTP1 Methylation Analysis of Postbiopsy Urine Specimens. Clinical Cancer Research 2673, 9 , 2673-2677.

17. Ho, S. -M., Johnson, A., Tarapore, P., Janakiram, V., Zhang, X., Leung, Y. -K., (2012). Environmental Epigenetics and Its Implication on Disease Risk and Health Outcomes. ILAR J., 53, $289-305$.

18. Hou, L., Zhang, X., Wang, D., \& Baccarelli, A. (2012). Environmental chemical exposures and human epigenetics. International Journal of Epidemiology, 41, 79-105.

19. Jirtle, R. L., \& Skinner, M. K. (2007). Environmental epigenomics and disease susceptibility. Nature Reviews Genetics, 8, 253-262.

20. Kim, K., Kim, D., Lee, S., Lee, I., Kang, J., \& Chang, Y. (2010). Association of Low-Dose Exposure to Persistent Organic Pollutants with Global DNA Hypomethylation in Healthy Koreans, 370(3), 370-374.

21. Li, J., Jin, H., \& Wang, X. (2014). Epigenetic Biomarkers : Potential Applications in Gastrointestinal Cancers. Hindawi 1-10.

22. Marsit, C. J., Eddy, K., \& Kelsey, K. T. (2006). MicroRNA Responses to Cellular Stress MicroRNA Responses to Cellular Stress, Cancer Research, 66, 843-848.

23. Maslansky, C. J., \& Williams, G. M. (1981). Evidence for an epigenetic mode of action in organochlorine pesticide hepatocarcinogenicity: A lack of genotoxicity in rat, mouse, and hamster hepatocytes. Journal of Toxicology and Environmental Health: Current Issues, 8, 121-130.

24. Mostafalou, S., \& Abdollahi, M. (2013). Pesticides and human chronic diseases: Evidences, mechanisms, and perspectives. Toxicology and Applied Pharmacology, 268, 157-177.

25. Nilsson, E. E., Anway, M. D., Stanfield, J., \& Skinner, M. K. (2008). Transgenerational epigenetic effects of the endocrine disruptor vinclozolin on pregnancies and female adult onset disease. Reproduction, 135, 713-721.

26. Pérez-Maldonadoa, I. N., Herrera, C., Batres, L. E., Gonza, R., D1, F., \& Ya, L. (2005). DDT-induced oxidative damage in human blood mononuclear cells. Environmental Research, 98, 177-184.

27. Rakitsky, V. N., Koblyakov, V. A., \& Turusov, V. S. (2000). Nongenotoxic ( Epigenetic ) Carcinogens: Pesticides as an Example. A Critical Review. Teratogenesis, Carcinogenesis, and Mutagenesis, 20, 229-240.

28. Rastogi, S. K., Tripathi, S., \& Ravishanker, D. (2010). A study of neurologic symptoms on exposure to organophosphate pesticides in the children of agricultural workers. Indian Journal of Occupational and Environmental Medicine, 14(2).

29. Reichard, J. F., \& Puga, A. (2010). Effects of arsenic exposure on DNA methylation and epigenetic gene Regulation. Epigenomics, 2(1), 87-104.

30. Ricketts, C. J., Hill, V. K., \& Linehan, W. M. (2014). Tumor-Specific Hypermethylation of Epigenetic 
Biomarkers, Including SFRP1, Predicts for Poorer Survival in Patients from the TCGA Kidney Renal Clear Cell Carcinoma ( KIRC ) Project. PLOS One, 9(1), 1-13.

31. Ross, J. a, Blackman, C. F., Thai, S.-F., Li, Z., Kohan, M., Jones, C. P., \& Chen, T. (2010). A potential microRNA signature for tumorigenic conazoles in mouse liver. Molecular Carcinogenesis, 49(4), 320-323.

32. Rusiecki, J. A., Baccarelli, A., Bollati, V., Tarantini, L., Moore, L. E., \& Bonefeld-jorgensen, E. C. (2008). Global DNA Hypomethylation Is Associated with High Serum-Persistent Organic Pollutants in Greenlandic Inuit. Environmental Health Perspectives, 116(11), 1547-1552.

33. Rusiecki, J. A., Freeman, L. E. B., Bonner, M. R., Alexander, M., Chen, L., Andreotti, G., Barry, K. H., Moore, L. E., Byun, H., Kamel, F., Alavanja, M., Hoppin, J. A., Baccarelli, A. (2016). High Pesticide Exposure Events and DNA Methylation among Pesticide Applicators in the Agricultural Health Study. Environmental and Molecular Mutagenesis, 1-11.

34. Sasaki, H., \& Matsui, Y. (2008). Epigenetic events in mammalian germ-cell development : reprogramming and beyond. Nature Reviews Genetics, 9, 129-140.

35. Shahrzad, S., Bertrand, K., Minhas, K., \& Coomber, B. L. (2007). Induction of DNA hypomethylation by tumor hypoxia. Epigenetics : Official Journal of the DNA Methylation Society, 2(2), 119-25.

36. Sharma, S., Kelly, T. K., \& Jones, P. A. (2010). Epigenetics in cancer. Carcinogenesis, 31(1), 27-36.

37. Shutoh, Y., Takeda, M., Ohtsuka, R., Haishima, A., Yamaguchi, S., Fujie, H., Komatsu, Y., Maita, K., Harada, T. (2009). Low dose effects of dichlorodiphenyltrichloroethane (DDT) on gene transcription and DNA methylation in the hypothalamus of young male rats: implication of hormesis-like effects. The Journal of Toxicological Sciences, 34(5), 469-482.

38. Song, C., Kanthasamy, A., Anantharam, V., Sun, F., \& Kanthasamy, A. G. (2010). Environmental Neurotoxic Pesticide Increases Histone Acetylation to Promote Apoptosis in Dopaminergic Neuronal Cells : Relevance to Epigenetic Mechanisms of Neurodegeneration, Molecular Pharmacolgy 77(4), 621-632.

39. Song, C., Kanthasamy, A., Jin, H., Anantharam, V., \& Kanthasamy, A. G. (2011). NeuroToxicology Paraquat induces epigenetic changes by promoting histone acetylation in cell culture models of dopaminergic degeneration. Neurotoxicology, 32(5), 586-595.

40. Stevenson, D. E., Walborg, E. F., North, D. W., Sielken, R. L., Ross, C. E., Wright, A. S., Xu, Y., Kamendulis, L. M., Klaunig, J. E. (1999). Monograph : Reassessment of human cancer risk of aldrin / dieldrin. Toxicology Letters, 109, 123-186.

41. Thienpont, B., Steinbacher, J., Zhao, H., Anna, F. D., Kuchnio, A., Ploumakis, A., Ghesquière, B., Dyck, L. V., Boeckx, B., Schoonjans, L., Hermans, E., Amant, F., Kristensen, V. N., Koh, K. P., Mazzone, M., Coleman, M. L., Carell, T., Carmeliet, P. (2016). Tumour hypoxia causes DNA hyper - methylation by reducing TET activity. Nature Publishing Group, 537(7618), 63-68.

42. Thomson, J. P., Moggs, J. G., Wolf, C. R., \& Meehan, R. R. (2013). Epigenetic profiles as defined signatures of xenobiotic exposure. Mutation Research - Genetic Toxicology and Environmental Mutagenesis, 764-765, 3-9.

43. Tsai, H., \& Baylin, S. B. (2011). Cancer epigenetics : linking basic biology to clinical medicine. Cell Research, $21(3), 502-517$.

44. Velázquez, A., Xamena, N., \& Creus, A. (2009). Mutagenic evaluation of the organophosphorus insecticides methyl parathion and triazophos in drosophila melanogaster. Journal of Toxicology and Environmental Health, $37-41$.

45. Wang, X., Zhou, S., Ding, X., Zhu, G., \& Guo, J. (2010). Effect of triazophos, fipronil and their mixture on miRNA expression in adult zebrafish. Journal of Environmental Science and Health. Part. B, Pesticides, Food Contaminants, and Agricultural Wastes, 45(7), 648-57.

46. Zhang, X., Wallace, A. D., Du, P., Kibbe, W. A., Jafari, N., Lin, S., Baccarelli, A., Soares, M. B., Hou, L. (2012). DNA Methylation aletrations in response to pesticide exposure in vitro. Environ Toxicol Pharmacol; 34(3): 959-968.

47. Zhang, Y.-J., Wu, H.-C., Shen, J., Ahsan, H., Tsai, W. Y., Yang, H.-I., Wang, L.-Y., Chen, S.-Y., Chen, -J. C., Santella, R. M. (2007). Predicting hepatocellular carcinoma by detection of aberrant promoter methylation in serum DNA. Clinical Cancer Research : An Official Journal of the American Association for Cancer Research, 13(8), 2378-84. 